\title{
Czech and Slovak Educators' Online Teaching Experience: A Covid-19 Case Study
}

\author{
Jozef Hvorecký ${ }^{1}$ (D), Michal Beňo ${ }^{1}$ (D), Soňa Ferenčíková ${ }^{2}$ (D), \\ Renata Janošcová ${ }^{3} \mathbb{D}$, Jozef Šimúth ${ }^{4}$ \\ ${ }^{1}$ Institute of Technology and Business in České Budějovice, Okružní 517/10, 37001 České Budějovice, Czech Republic \\ ${ }^{2}$ Faculty of Commerce, University of Economics in Bratislava, Dolnozemská cesta 1, 85235 Bratislava 5, Slovak Republic \\ ${ }^{3}$ Faculty of Economics, University of Finance and Administration, Estonská 500, 10100 Prague 10, Czech Republic \\ ${ }^{4}$ School of Management, City University of Seattle in Slovakia, Panónska cesta 17, 85104 Bratislava, Slovak Republic
}

Corresponding author: Jozef Hvorecký (hvorecky@mail.vstecb.cz)

\begin{abstract}
The surge in interest in online teaching increased not only due to the pandemic. It had been growing even before. The main objective of this study is therefore to explore how online teaching has changed. It addresses experience and opinions of educators of Czech and Slovak universities in the period from the first days of the COVID-19 lockdown (March 2020) till the peak of its second wave (May 2021). To examine the impact of disharmony, the authors investigated Czech and Slovak university educators' activities and behaviour during their online teaching. A descriptive statistics approach was applied. A total of 172 educators participated in our online survey. Our results reveal that online teaching has become a fundamental component of their education. Our outcomes demonstrate their low preparation for this unexpected event as well as their quick adaptation to the new situation. Additionally, data indicate that their difficulties reconcile their previous experience and teaching practices with online teaching. Finally, they show that about half of them are still sceptical about the future of online education and dream of return to traditional teaching. Our results also indicate that universities should facilitate their efforts in developing online education methodology and overall support to their educators.
\end{abstract}

\section{Keywords}

COVID-19 pandemic; Experience in online education; Higher education; Online teaching; Social informatics.

\footnotetext{
Citation: Hvorecký, J., Beňo, M., Ferenčíková, S., Janošcová, R., \& Šimúth, J. (2021). Czech and Slovak Educators' Online Teaching Experience: A Covid-19 Case Study. Acta Informatica Pragensia, 10(3), 236-256. https://doi.org/10.18267/j.aip.162 


\section{Introduction}

Already before COVID-19, distance education was widespread in e-coursework among non-traditional students (Allen and Seaman, 2010), in particular among those who are employed or have family obligations (Aslanian, 2001) and/or are older, have a full-time job, or have other challenges in coming to the campus (Makoe et al., 2008). One can say that education and technology become inseparably linked in the field of distance and lifelong education (Lipovská et al., 2014). Further, the conceptualization of social informatics was exposed with the increasing role of information and communication technologies (Vehovar, 2006). Our paper is in the vein of Kazmer and Haythornthwaite's (2005) statement that online education calls for attention from various perspectives looking at the transformative effects of this social and technological innovation. Barkhatova et al. (2017) emphasize the society's requirements for quality information training of a personality.

The COVID-19 pandemic introduced the same relation into regular in-class education. It forced all educational institutions to replace their standard (face-to-face) mode of education to the online (face-todisplay) mode. This replacement has been a common concern among educators for long (Conrad, 2004). Classrooms had to be set up at home-based premises, which offered an opportunity for innovation and creativity. Compared to previous modal shift, which had taken decades, the recent change was sudden and massive. The authors agree with Dhawan (2020) that e-learning is a necessity under such circumstances. Educators were requested to change their teaching mode to online education even at schools and universities with no previous experience of it. In accordance with Hvorecký and Beňo (2021, p. 300), e-learning and e-working resemble each other in "giving up daily interactions with people who are working in the same location". They further explain that "for some types of students (especially for adult working professionals), combined (on-site and online) learning and solely online learning is preferred as the only possibility to complete or continue courses or education. For some students, such as recent high-school graduates, an experience of learning and living in campus is preferential." In the post-COVID period, new quality and service will therefore be required (Currie et al., 2020).

Departments of all Czech and Slovak universities had to undergo the same adaptation. Based on two different reports addressing pre-COVID online education (Beblavý et al., 2019; Preply, 2020), one can conclude that teachers in the Czech and Slovak Republics preferred in-class teaching because (a) they were used to it and (b) no-one had ever asked them to do anything else.

Below, we study several aspects of the change and its potential effects on future university functions. Our research addresses the periods of the first and second pandemic waves (March 2020 to May 2021 with a few short interruptions). The pandemic offered an exceptional opportunity to analyse processes evoked by this sudden external factor. To study its commencement, progress and effects, we administered an online survey addressing the activities of university educators, their experience with online educational methods and presence/absence of support from their university. During that period, they had enough time to learn their lessons necessary for developing future conduct scenarios at both individual and organizational levels.

The Roman philosopher Seneca said: "Luck is what happens when preparation meets opportunity". The extracted facts allow us to make conclusions about the preparation of universities and their staff for providing large-scale and lasting online education. Janošcová and Hvorecký (2020) suggested that universities should design and develop online education strategies. In the questionnaire, the educators expressed their opinions on their previous experience, training and institutional support during the pandemic. As our results indicate, the suggested systematic policies have rarely been applied by Czech and Slovak universities before. In our research, we were therefore more interested in the organization of online education and its performative processes and support than its methodology because it has to be 
very specific for each and every course. Without question, methodological issues are extremely important but our snowball sample formation would not allow us to address detailed questions about it. As a result, we included only those issues which are shared by all online courses.

The target of our survey was the universities' social, organizational, managerial and educational processes from the social informatics point of view. Social informatics research studies the social context of information technology development and concentrates on significant influences of ICT on human beings, i.e., on their consequences for work, organizations and other social relationships (Kling, 1999). Even though course design and development, testing and examinations, for example, are an important part of education, they are too specific for each subject. Thus, we focused on a higher (more general) level, i.e., whether educators' experience with online teaching will affect their future educational practices.

There is a reason for skipping the technology infrastructure issues, too. Czech and Slovak universities have been building their networking infrastructure since the 1970s and updating it regularly. As a result, all departments are equipped and connected fairly well. One could question students' access from home. Eurostat data (2021) show that the Internet environments in both the Czech and Slovak Republics are welldeveloped, too. Before the pandemic, the saturation of households with the Internet was $88 \%$ in the Czech Republic (in 2019) and 85\% in Slovakia. The proportion grew during the COVID-19 period to 89\% in the Czech Republic and 91\% in Slovakia. The Slovakian leap of 6\% indicates that parents who are interested in their children's education (and/or were forced to work from home) support their households with technology to build optimal conditions. As the EU27 average in 2021 is $89 \%$, the figures indicate a comparable saturation with the Internet in our study countries and, consequently, good preconditions for online education among university students.

Our main question is whether university students could study online comfortably and efficiently. In particular, we ask whether the universities had built a relevant scaffolding for online study prior to the pandemic, how they strengthened it during the period and, finally, whether they are ready to learn from it and to expand the weight of online education. University students themselves are not the subject of our study. We have studied the flow of online education and its changes during the pandemic. Its smooth flow is a duty of universities, not of students. Moreover, young people have usually fewer problems with changing environments and rules.

A recent study highlights that for the younger generation, and especially for vulnerable adolescents, the COVID-19 crisis poses significant risks in the field of education among other fields (OECD, 2020). So, our priority was concentrated on the parts of the process which would be likely more affected. Today's students belong to Generation Z dubbed "digital natives" (Turner, 2015); they are used to online communication much more than their teachers. Potential problems could relate to their previous preparation. Nevertheless, it is not bad. The Czech Republic's PISA (Programme for International Student Assessment) results are average and Slovakia's are a bit lower. In addition, preconditioning knowledge can hardly influence the outcomes substantially because for every individual it remains the same regardless of his/her study mode.

On the other hand, the teachers might face difficulties more easily - not because of technology but because of methodology. Above, we referred to studies of Beblavý et al. (2019) and Preply (2020) pointing to it. Moreover, Hall et al. (2019) found out that passive methods of education prevail at the Slovak universities - with lecturing dominating above all. In bachelor and master programs, $83.8 \%$ of educators apply it in their courses. Student-centred learning methods based on dialogue are less frequent. This approach contradicts the philosophy of virtual classrooms (Palloff and Pratt, 2007; Salmon, 2011), where the educator is not the sole source of information. He/she rather plays the role of moderator and facilitator. As we show below, the gap in teachers' experience was reflected in their behaviour. 
In our paper, we study the activities of university educators, their stepwise understanding of online educational methods, and their support from the university. We investigate their behaviour during the pandemic period and ask whether they learnt any lessons necessary for developing their future scenarios at both individual and organizational levels.

\subsection{Online learning and teaching becomes crucial}

As Kling et al. (2005) underline, "ICTs do not exist in social or technical isolation. Their 'cultural and institutional contexts' influence the ways in which they are developed, the kinds of workable configurations, how they are implemented and used, and the range of consequences that occur for organizations and other social groupings". Our paper focusses on the influence of ICT on educational processes and their changes as a result of the pandemic.

As education is the principal function of any university, it had played a significant role in university life even before the COVID-19: technology for teaching remotely was on a constant rise (Duffin, 2020). Similarly, Wegner et al. (2019) state that technology used to deliver coursework in higher education has seen a veritable explosion. According to Valverde-Berrocoso et al. (2020), Massive Open Online Courses (MOOC) dominated as the e-learning modality. All this has had effects on university life.

In 2017, 33.5\% of American higher-education students were enrolled in some form of distance or online learning. Since 2020, 98\% of universities have moved to online classes (ThinkImpact, 2021). Online learning increases retention (Ditacademy, 2017). Abou El-Seoud et al. (2014) observe that utilization of interactive features of e-learning increases motivation of undergraduate students for the learning process. Burçin Hamutoğlu et al. (2021, p. 111) observe that students with previous Internetbased education experience have a higher level of awareness of the methods and techniques used in the course. Another study from Slovenia indicates that the overall perception in relation to ecourses, their coherence with face-to-face teaching and the teacher's responsiveness had a significant impact on the students' perception of the usefulness (Aristovnik et al., 2016). A recent study stresses that e-learning adoption and e-learning attitude do not directly predict academic achievement in e-learning but enhance digital readiness and academic engagement (Kim et al., 2019). According to Zolochevskaya et al. (2021), ICT has a substantial positive effect on the total success of students in universities. Latest research confirms the overall positive attitude of students and faculty members towards the use of online and e-learning modules/methods (Gerasimova et al., 2018). Butorac et al. (2011, p. 426) reveal that students value the most completeness, organization and design of educational materials, as well as teachers' online engagement, especially in good e-course management, regular communication and timely provision of feedback. The author further discovered that preferences for exclusively online and/or blended learning are dominant in a group of students having better average study grades (A or B), as well as in a group having shorter study experience.

Carey (2020) explains that colleges exist in a state of constant electronic connectivity. He further adds that online education accomplishes at least three distinct things: distance, scale and personalization. Liguori and Winkler (2020) highlight that innovative solutions by institutions are crucial. According to students, online learning is very helpful to $40 \%$ of them (Duffin, 2020); 50\% of them were active in online courses on various platforms (Keegan, 2021) and women are more likely to participate in distance learning (NCES, 2019). Current data from one study demonstrate that there are equal opportunities for males and females in e-learning, and that female students use e-learning platforms very well (Vadakalu Elumalai et al., 2020, p. 744). 
Social informatics studies related to universities are done worldwide. A study from Dubai demonstrates that e-learners have shown a very high level of understanding concerning the potential and value of e-learning (Gokah et al., 2015). Gedeon and Khalil (2015) stress that the primary barriers to e-learning development persist due to non-implementation of e-learning regulations by governments. A recent study from Iran highlights cultural barriers to e-learning implementation, too (Ahmadi and Nourabadi, 2020). Franklin et al. (2018, p. 94) recommend the management of King Khalid University to ensure that potential learners of the university accept learning via web-based technology. In addition, university management should certify that learners and instructors have the required technical competency. Environments supporting social contacts can also reduce some negative consequences of online education, e.g., feelings of isolation (Dávideková and Hvorecký, 2017).

\subsection{Reasons for having a university-wide online education strategy}

The positivist's view of classrooms as teacher-centred environments contrasts with the constructivist's one presenting learning as a student-centred method (King, 1993). Barker (2003) accented a shift from teacher-centred instruction to learner-centred instruction, too. Espinoza (2012) suggests another paradigm shift: learning from technology to learning with technology. Chizmar and Williams (2001) are of the opinion that learning pushes technology. Online learning in higher education boosts access for all present learners and as such provides a new access tool for previously underserved learners (Sener, 2010).

Mitchell (2014) emphasizes that following online teaching strategies could enhance students' perception of engagement, increase retention and satisfaction. According to Cox and Marshall (2007, p. 3), "skilful use of ICT (Information and Communication Technology) by the teachers links to careful pedagogical automation, capacity, range and interactivity". HEA (2015, p. 4) emphasizes: "When well supported, [flexible learning] positively impacts recruitment, retention and progression; widens participation; and offers opportunities to learners of all ages, backgrounds, ethnicities and nationalities".

Such a substantial change of university functions must be made systematically as part of a universitywide online educational strategy. Under that, we understand a set of written organizational guidelines as well as written and unwritten methodological procedures serving as a basis for standardized execution of a study program over the Internet. It specifies design, development and continuing improvement of both (online and on-site) streams of courses, synchronizes their specific activities, optimizes them and coordinates them in the time schedules of all campuses sharing the courses. When well developed, it allows simple and smooth transfer between modes and locations. According to Hvorecký et al. (2021), the key components of the strategy are:

- Acceptance of the strategic importance of massive online education leading to a shift in the educators' way of thinking and resulting in the recognition of online education as an equal alternative to standard classroom delivery.

- Creation of supportive digital content for two (i.e., online and on-site) versions of each course with identical learning objectives using optimal specific tools of each particular mode.

- Organizing the system of staff development and in-service teacher training based on elaborated methodologies, long-term experience and best practice.

- Development of virtual classrooms, laboratories and courses combining the specific course content and a standardized template for all courses. Such uniformity minimizes the time waste caused by the necessity to learn to operate the course.

- Excellent execution of online courses covering all their functions (content delivery, teacher-student collaboration and feedback, transparent grading, etc.) A quality assessment team should control their excellence and guarantee that online education will achieve its expected level. 
- Sustainable development of online methodology and its practices addressing uninterrupted execution of courses and their systematic improvement and innovation.

In accordance with Andrade (2016), common higher education traditions and cultures represent a fundamental obstacle to online learning paradigms. We will present some of their consequences below.

\section{Materials and Methods}

This study adopted a quantitative approach. From 20 April to 10 May 2021 (at the peak of the second wave of the COVID-19 pandemic), an online web survey was distributed among Czech and Slovak educators aged 20 years or older. A rigorous approach to research based on a large sample, a targeted survey method and reducing nonresponse error (Ponto, 2015) was implemented. An English questionnaire was formed first but was then translated into both official languages of the countries where the survey was conducted. A set of open-ended and closed-ended questions with Likert scales and numerical ranges were included in the questionnaire. The questionnaire design was tested with a group of respondents before its finalization. Educator demographics such as age, gender, type of contract, country and type of university were collected at the beginning of the survey. Responses to the questionnaire were anonymous and voluntary. This fact was emphasized in the e-mail invitation to the survey. All participants who engaged in the survey were fully informed regarding confidentiality, privacy, sensitivity and data protection. A consent form was issued.

\subsection{Sample}

Data relevant to the six above strategic components were collected from university educators as a systematic sample. Obviously, this sample is seen as unrepresentative of the entire population because there was no time for a prolonged preparatory period which would be formed using one of the following ways:

a) address all university educators in both countries, or

b) form a stratified sample from a well-specified set of universities.

Snowball sampling was implemented to gather information to access specific groups of people (Naderifar et al., 2017). As the authors of this paper are experienced online educators with many contacts among online education specialists around both countries, they addressed them and asked for distributing the questionnaire to as many colleagues as possible (which is the principle of so-called exponential nondiscriminative snowball sampling). The initial group consisted of 50 specialists from the Czech Republic and Slovakia (25 from each country). To nudge them and their respondents, we promised to send them a copy of the paper (Hvorecký et al., 2021) that served as a guideline for our questionnaire design. A dozen of them applied and received it.

A total of 172 educators responded (67 from Czech universities and 105 from Slovakian ones). These are the key characteristics of the group:

- 146 educators came from public universities, 26 from private ones,

- there were 108 females and 64 males,

- the age group of 40-60 had 88 members, the 20-39 group 44 persons, the $60+$ group numbered 40 educators,

- 154 teachers worked full-time and 18 part-time.

\subsection{Data analysis and evaluation of survey results}

Due to the snowball sample, we have no opportunity to know how representative of the population the sample is. For this reason, our principal research method is descriptive statistics with numbers that are used to summarize and describe unrepresentative data which do not involve generalizing beyond the 
data at hand. Our extensive set of data covers demographic data, preferred teaching modes prior to and during the pandemic, the adaptation period and its effects on the teachers' classroom activities and their potential development in the future. In most cases, we grouped the teachers' responses, aggregated and then interpreted them. To derive a true picture, we often combined several of these outcomes, juxtaposed them - and reinterpreted, if needed.

We concentrated on the following questions:

- Have educators preferred synchronous (real-time interaction with a group) or asynchronous (no real-time interaction with a group) communication? What are the differences between the prepandemic and pandemic periods?

- Will they apply some online teaching elements in their teaching even after the pandemic and how?

- Do teachers feel the need to develop their skills in e-pedagogy in the future?

Respondents may give consistently high or low ratings, reflecting the evaluator's bias that detracts from the validity of the results (Isaac and Michael, 1997, p. 137). Generally, in terms of coverage, online surveys using only samples of digital users cannot be not generalized to the general public (Fricker, 2015).

In our survey, the educators expressed their interest in presenting their opinions in order to study the current state of online education and its near future. In our survey, the higher response rates were associated with lower nonresponse bias. The authors did not follow the myopic focus on large sample size and the idea that a larger sample possibly equates to sample representatives and generalizability.

In the Discussion section, we consider the degree of their validity. We sum up the given values and then process them in order to accumulate the educators' individual opinions and feelings to those characterizing the group. As their predictive value is restricted by the method used, we denote them as "indicators". In the Discussion and Conclusion sections, we analyse to what degree these indicators can be extrapolated to the entire university system despite their subjective character.

\section{Results}

In this part, the authors refer to the process of analysing data obtained from the educators.

\subsection{Respondents' experience of online teaching prior to the pandemic and triggered change}

It is notable that the educators in our sample had generally not been prepared for online teaching. In total, more than half of them (51.8\%) had no previous experience of teaching remotely. Only $23.8 \%$ of them teach remotely regularly and $24.4 \%$ occasionally. Across the board, the results reveal a low portion of online education at Czech and Slovak universities. A more detailed picture indicates proportional differences between the countries; see Table 1 .

Table 1. Online teaching experience by country.

\begin{tabular}{llccc}
\hline Country & Educators & Never & Occasionally & Regularly \\
& $\mathrm{N}$ & $\mathrm{N}(\%)$ & $\mathrm{N}(\%)$ & $\mathrm{N}(\%)$ \\
\hline CZ & 67 & $42(62.7 \%)$ & $17(25.4 \%)$ & $8(11.9 \%)$ \\
SK & 105 & $47(44.7 \%)$ & $25(23.8 \%)$ & $33(31.4 \%)$ \\
\hline
\end{tabular}

There is a difference. The proportions of those teaching occasionally is practically the same but there is approximately a $20 \%$ difference in favour of Slovakia in the two remaining characteristics. In total, 83 (25 in the Czech Republic and 58 in Slovakia) educators had certain experience of online teaching. 
Table 2 shows their teaching modes used prior to and during the COVID-19 pandemic. Notice that the sum of values in the first row is greater than 83; in the second row greater than 172 . This is caused by the fact that some of them practised their combinations. Notice also that the percentages in the first row are counted out of 83 , in the second one out of 172 .

Table 2. Online teaching modes before and during the pandemic.

\begin{tabular}{ccccc} 
& \multicolumn{3}{c}{ Number of teachers using the given online teaching mode } \\
\hline Period & Synchronous & Asynchronous & Combined & Other \\
\hline Before & $11(13.3 \%)$ & $55(66.3 \%)$ & $14(16.9 \%)$ & $3(3.6 \%)$ \\
During & $161(93.6 \%)$ & $85(49.4 \%)$ & $94(54.7 \%)$ & $7(4.1 \%)$ \\
\hline
\end{tabular}

All four increments are substantial. On the other hand, their expressive value can be questioned with regard to the fact that their growth is a result of external powers.

Our triad of questions (on the synchronous and asynchronous modes as well as their combination) can be seen as tricky and superfluous. Nevertheless, it was done on purpose. As we wanted to get a realistic picture, it was posted to make certain that the respondent will not understand synchronous and asynchronous modes as exclusive options. All responses with Yes in both variants A and B were included in the sum as well as those in which the person only marked Yes at "combined". Course content delivery using other (i.e., less standard) methods includes Skype or social media communication, YouTube videos and online tests. They were usually exploited as emergency solutions in the absence of more standard options.

\subsection{Specific change of online teaching modes}

A deeper look at Tables 1 and 2 in the previous chapter shows that just 11 out of 83 then teaching educators preferred collaborative tools with a synchronous communication (MS Teams, Google Meet, Zoom, TeamViewer, BBB, etc.) prior to the pandemic. The majority used asynchronous communication via learning management systems (LMS) such as Moodle, Blackboard, TalentLMS, etc. A combination was used by 14 educators. Only 3 educators preferred another format, especially email or phone calls.

Table 2 above demonstrates a sudden change in the proportion between the synchronous and asynchronous modes. The educators exploited the synchronous mode (161) and the combined mode (94) more frequently than the purely asynchronous one (85). The greatest share is evidently observed in the synchronous mode, in which the teachers and their students are present in a face-to-display teaching environment. It grew almost 15 times more compared to the pre-COVID period. There is an explanation: As mentioned above, the number of experienced online educators was not high. Hall et al. (2019) point to the prevalence of lecturing at Czech and Slovak universities. A person accustomed to it would hardly change his/her habits instantly upon an order. In such a situation, he/she logically tries to mimic his/her habits to the maximum degree. The most natural choice is lecturing via a synchronous tool.

There is a rise in asynchronous online education, too, but its growth was much smaller. It may look as a surprise because Moodle has been widespread more at Czech than Slovak universities (Moodle, 2021). In fact, no surprise happens. Asynchronously delivered courses must be first carefully designed, developed and only then publicized and applied. That could hardly be done within the next few days following the lockdown because the courses were to continue instantly. To deliver a synchronous lecture is almost the same as to do it in front of the classroom - the teachers can exploit their existing notes and slides. In the case of an emergency, a synchronous lecture can be prepared much faster and, therefore, it represents an effective quick solution. Their behaviour was rather natural in the atmosphere of chaos at some institutions. As an educator says in his/her open answer: "Our school (management) did not specify what and how we should teach... They just asked us to keep the number of contact hours." 
Due to this, the relationship between the "pure" (i.e., synchronous and asynchronous) modes of delivery deserves an additional analysis. As all 172 lecturers were forced to teach online, our data demonstrate interesting shifts:

- Teachers with no previous experience: All 88 educators selected the synchronous mode; a minority (31 of them) combined it with the asynchronous mode.

- Teachers teaching online occasionally: In the past, only 5 of 42 taught using the synchronous mode and 30 used exclusively the asynchronous mode - the number grew to 37 . The number of exclusive users of the synchronous mode declined slightly from 30 to 27.

- Teachers teaching online regularly: Prior to the pandemic, there used to be 41 regular online teachers. 6 of them used exclusively the synchronous mode - their number grew to 38 . The number of users of the asynchronous mode grew from 26 to 28 . This is the only group with an increase in the asynchronous mode of teaching - likely their previous experience allowed them to do it fast.

\subsection{Profiling teachers' online education training}

Even if the teachers were not teaching online, were they trained to do it? The question is not new. Already Lichoro (2015) found that instructors did not perceive being satisfactorily ready to teach online. In our case, only 55.2\% (95) out of 172 educators underwent some training prior to the pandemic, with 32 among them (i.e., $18.6 \%$ of the total) more than once. Of course, this means that the remaining 77 lecturers can be considered unprepared for online education at the moment of the pandemic breakout.

On top of it, among the 95 trained educators completing at least one training, 52 had never taught online prior to the pandemic. Out of the 32 of them who had passed more than one training, 10 had never taught online. Without having any practice, there can be great concerns about the practical value of such training. However, the trainees had some idea of what to expect.

As a direct result, we add the fact that 27 out of the 83 educators (i.e., 32.5\%) who were teaching online prior to the pandemic did it without any training. Thus, the quality of pre-pandemic preparation was quite confusing and the decision "to teach or not to teach" often depended on the individual or his/her small group.

\subsection{Transfer time during first weeks of the pandemic}

Both on-site and online course design and planning are time-consuming. Switching from one to the other is not easy. We were therefore interested in whether and how the teachers struggle with the sudden lockdown and the necessary change of approach. The survey question is: "How long after the interruption of classroom education did you manage to adapt to a regular rhythm of online communication with your students?" It has three options: one week - three weeks - not before the end of the semester/trimester.

As the educators were aware of and understood the pandemic restrictions, they did a remarkable job. Only $5.8 \%$ of them were not able to get back to the work rhythm before the term ended. It also indicates their high degree of teacher flexibility and, consequently, the high probability that the business might run "as usual" quite soon after the breakout of the next wave.

Table 3. Comparing previous experience and adaptation period.

\begin{tabular}{lcccc}
\hline Teaching online before & $\begin{array}{c}\mathrm{N} \text { of } \\
\text { teachers }\end{array}$ & $\begin{array}{c}\text { One week } \\
\mathrm{N}(\%)\end{array}$ & $\begin{array}{c}\text { Three weeks } \\
\mathrm{N}(\%)\end{array}$ & $\begin{array}{c}\text { Not during } \\
\text { term } \\
\mathrm{N}(\%)\end{array}$ \\
\hline Never & 89 & $59(66.2 \%)$ & $23(25.8 \%)$ & $7(7.8 \%)$ \\
Occasionally & 42 & $31(73.8 \%)$ & $8(19.0 \%)$ & $3(7.1 \%)$ \\
Regularly & 41 & $37(90.2 \%)$ & $4(9.8 \%)$ & $0(0.0 \%)$ \\
\hline
\end{tabular}


Table 3 shows particulars of the adaptation periods depending on the individual's online teaching experience. The less experienced educators needed a longer average period to adapt. Out of the 89 teachers who did not teach online before the pandemic, 59 (66.2\%) were able to catch their rhythm within a week, $23(25.8 \%)$ within three weeks and seven $(7.8 \%)$ of them did not do so during the first term. On the other hand, occasional online educators needed shorter time to adapt: $73.8 \%$ in one week, $19 \%$ in three weeks and $7.1 \%$ not during the term. In the group teaching online regularly, it is not surprising that all of them were capable to operate within three weeks: $90.2 \%$ of those teaching regularly adapted instantly, less than $10 \%$ needed more than one week. It implies that the groundwork pays off.

\subsection{Self-assessment of online teaching}

We applied self-assessment as a metric of online teaching preparedness. The statement sounded: "Not taking into account some parts of learning materials which require specific conditions (lab equipment or nonstandard software applications), I am able to organize my online teaching at a satisfactory quality level."

Unquestionably, such self-evaluation is subjective but it still offers a glimpse at personal attitudes and comfortability. We believe that after more than a year of online teaching (almost three semesters), the educators are capable of assessing their performance. Therefore, their answers propose a reasonably good level of (subjectively estimated) quality. Table 4 shows the results. Roughly, more than $37.8 \%$ are certainly satisfied and more $44.8 \%$ are likely satisfied with their quality compared to $14.6 \%$ of likely not satisfied and $2.9 \%$ certainly not satisfied as shown in Table 4 .

Table 4. My online teaching is at a satisfactory level.

\begin{tabular}{lc}
\hline Satisfaction level & $\mathrm{N}(\%)$ \\
\hline Certainly yes & $65(37.8 \%)$ \\
Likely yes & $77(44.8 \%)$ \\
Likely not & $25(14.6 \%)$ \\
Certainly not & $5(2.9 \%)$ \\
\hline
\end{tabular}

As the most often "grade" is Likely yes, the data can be interpreted as educators' ability to look critically at their performance despite the prevalence of positive evaluations. Surprisingly, if we look at details of this self-evaluation, Table 5 demonstrates almost no difference between those teachers without any training and those having just one training - the values in their rows are almost identical. Inversely, there is a difference between the members of these two groups and those who completed more than one training. The number of trainings seems to play a role only if it is two and more.

Table 5. Relation between teacher training and quality of their online teaching.

\begin{tabular}{lccccc} 
& & \multicolumn{4}{c}{ Self-evaluation of teaching quality } \\
\cline { 3 - 6 } Training & $\mathrm{N}$ of & Certainly yes & Likely yes & Likely not & Certainly not \\
\hline None & educators & $\mathrm{N}(\%)$ & $\mathrm{N}(\%)$ & $\mathrm{N}(\%)$ & $\mathrm{N}(\%)$ \\
One & 77 & $27(35.1 \%)$ & $35(45.5 \%)$ & $13(16.9 \%)$ & $2(2.6 \%)$ \\
More than one & 63 & $22(34.9 \%)$ & $28(44.4 \%)$ & $11(17.5 \%)$ & $2(3.2 \%)$ \\
\hline
\end{tabular}

\subsection{Learning by teaching}

During their year of online teaching experience, the educators had to learn to do it. This positive trend in the transfer of learning objectives is observable from their responses to the question: "I have been able to adapt my course(s) in such a way that my learning objectives are affected only negligibly." Their positions are in Table 6. 
Table 6. Ability to transfer learning objectives effectively.

\begin{tabular}{lc}
\hline Agreement level & $\mathrm{N}(\%)$ \\
\hline Certainly yes & $96(55.8 \%)$ \\
Likely yes & $71(41.3 \%)$ \\
Likely not & $5(2.9 \%)$ \\
Certainly not & $0(0.0 \%)$ \\
\hline
\end{tabular}

Quality of online teaching closely relates with quality of the teacher-student communication. It was behind the question: "Due to these adoptions and experience, our mutual communication with students over the internet is now regular and intensive."

Compared to the above transfer of learning objectives, the educators seem to be a bit more sceptical about the quality of their communication with students (see Table 7). It is valued as less effective by 16 out of 172 educators.

Table 7. Successful communication.

\begin{tabular}{lc}
\hline Agreement level & $\mathrm{N}(\%)$ \\
\hline Certainly yes & $88(51.2 \%)$ \\
Likely yes & $68(39.6 \%)$ \\
Likely not & $14(8.1 \%)$ \\
Certainly not & $2(1.7 \%)$ \\
\hline
\end{tabular}

Their objections often address impersonal communication: "I miss their body language from which the teacher recognizes that the content has not been comprehended." or "A much longer period of resolving misunderstandings and confusions is a great minus compared to the face-to-face contact."

Table 8 shows a gender difference. It is likely a result of the communication styles as stated by Montgomery and Norton (1981). At the same time, based on their verbal feedback in their open answers, their mutual communication was adequate, timely and prompt.

Table 8. Quality of communication by gender.

\begin{tabular}{llllll}
\hline Gender & Total & $\begin{array}{l}\text { Certainly yes } \\
\mathrm{N}(\%)\end{array}$ & $\begin{array}{l}\text { Likely yes } \\
\mathrm{N}(\%)\end{array}$ & $\begin{array}{l}\text { Likely no } \\
\mathrm{N}(\%)\end{array}$ & $\begin{array}{l}\text { Certainly not } \\
\mathrm{N}(\%)\end{array}$ \\
\hline Male & 64 & $25(39.1)$ & $31(48.4)$ & $8(12.5)$ & $0(0.0)$ \\
Female & 108 & $63(58.3)$ & $37(34.2)$ & $6(5.6)$ & $2(1.8)$ \\
\hline
\end{tabular}

\subsection{Providing educator support}

We have seen various weaknesses in pre-pandemic training. They certainly affected the teachers' performance - and they had to react to the new situation. Troubles often initiate collaboration. We tested it by the question: "With my colleagues, we exchange our experiences and consult potential improvement of our online courses." Their responses are in Table 9. Only 19 of them never consulted their colleagues. A prevailing majority did: 119 occasionally and 34 regularly. 
Table 9. Consulting colleagues.

\begin{tabular}{lc}
\hline Frequency level & $\mathrm{N}(\%)$ \\
\hline Never & $19(11.0 \%)$ \\
Occasionally & $119(69.2 \%)$ \\
Regularly & $34(19.8 \%)$ \\
\hline
\end{tabular}

One would expect that the educators with no previous online learning experience would consult more intensively than the rest. Table 10 shows that it is not the case. Regardless of the educator's starting point, the sum of occasional and regular consultations is at the level of $80 \%$. To get the correct answer one would have to ask "who was consulting whom". This might clarify the reason for the greatest portion of regular consultations among the best trained educators. Our formulation of the question did not evoke that. Thus, it deserves additional research.

Table 10. Intensity of consultation.

\begin{tabular}{lccc}
\hline $\begin{array}{l}\text { Teaching before } \\
\text { the pandemic }\end{array}$ & $\begin{array}{c}\text { Never consulting } \\
\mathrm{N}(\%)\end{array}$ & $\begin{array}{c}\text { Consulting occasionally } \\
\mathrm{N}(\%)\end{array}$ & $\begin{array}{c}\text { Consulting regularly } \\
\mathrm{N}(\%)\end{array}$ \\
\hline Never & $10(11.2 \%)$ & $64(71.9 \%)$ & $15(16.6 \%)$ \\
Occasionally & $4(9.5 \%)$ & $29(69.0 \%)$ & $9(21.4 \%)$ \\
Regularly & $5(12.2 \%)$ & $26(63.4 \%)$ & $10(24.4 \%)$ \\
\hline
\end{tabular}

The $80 \%$ of consultation requests is an encouraging number. However, Table 11 indicates that the educators are not thinking about changing it into a regular self-education activity. It comes out from their responses to the statement: "With my colleagues, we organize (or plan to organize) a seminar on the didactics of our courses."

Table 11. Planning to organize a seminar in future.

\begin{tabular}{lcccc}
\hline $\begin{array}{l}\text { Consulting with } \\
\text { colleagues }\end{array}$ & $\begin{array}{c}\text { Certainly yes } \\
\mathrm{N}(\%)\end{array}$ & $\begin{array}{c}\text { Likely yes } \\
\mathrm{N}(\%)\end{array}$ & $\begin{array}{c}\text { Likely not } \\
\mathrm{N}(\%)\end{array}$ & $\begin{array}{c}\text { Certainly not } \\
\mathrm{N}(\%)\end{array}$ \\
\hline Never & $3(1.7 \%)$ & $3(1.7 \%)$ & $5(2.9 \%)$ & $8(4.6 \%)$ \\
Occasionally & $4(2.3 \%)$ & $16(9.3 \%)$ & $69(40.1 \%)$ & $30(17.4 \%)$ \\
Regularly & $6(3.5 \%)$ & $9(5.2 \%)$ & $14(8.1 \%)$ & $5(2.9 \%)$ \\
\hline
\end{tabular}

One would expect their willingness to get a systematic platform for it - a seminar to develop their skills. The responses "Certainly yes - Likely yes" represent a minority in their rows as their summations indicate:

- $31.6 \%$ of those who never consulted with their colleagues (out of 19);

- $16.8 \%$ of those who needed occasional consultations (out of 119);

- $41.2 \%$ of those who were doing it regularly (out of 34 ).

The organization of seminars in future remains uncertain.

\subsection{Lessons learnt by e-teachers}

COVID-19 caused a global movement from face-to-face to face-to-display education. For lecturers, there might have existed a myriad of reasons to avoid online instruction in the pre-COVID time. Then, all did work more than a year in their virtual environments. Due to it, they presumably collected a quantum of experience which they can exploit in their future practice. 
Table 12. Transferring online experience into daily courses.

\begin{tabular}{lc}
\hline Agreement level & $\mathrm{N}(\%)$ \\
\hline Certainly yes & $80(46.5 \%)$ \\
Likely yes & $67(39.0 \%)$ \\
Likely not & $20(11.6 \%)$ \\
Certainly not & $5(2.9 \%)$ \\
\hline
\end{tabular}

It inspired us to pose the question: "After the pandemic, I will exploit my experience during online education in my daily courses." Their responses are in Table 12. Most teachers found online education practices appropriate for implementing into their daily courses. Only $14.5 \%$ of the educators do not feel sufficient inspiration. This inspiration could come from their communication with their students. That is why we asked a similar question: "I will incorporate some ideas of my students into the future course content." See Table 13 for the responses.

Table 13. Teachers incorporating their students' ideas.

\begin{tabular}{lc}
\hline Agreement level & $\mathrm{N}(\%)$ \\
\hline Certainly yes & $69(40.1 \%)$ \\
Likely yes & $78(45.3 \%)$ \\
Likely not & $19(11.0 \%)$ \\
Certainly not & $6(3.5 \%)$ \\
\hline
\end{tabular}

According to the data obtained, online teaching is not based on what knowledge the professors can impart, but instead on what students need letting to express their opinions, reflect, act and cultivate their professional skills. The students' commitment to learning online looks high because $85.4 \%$ of the educators will incorporate some of their ideas into their future courses. Again, the prevailing majority of their reactions are positive. Less than $15 \%$ are not ready to get inspired. This confirms the previous findings.

\subsection{Effects of age and gender of e-educators on online learning sustainability}

E-learning sustainability can be achieved only when the educators believe in it. To learn more about their trust, we asked a question: "Is the current internet-supported education just a replacement of traditional methods and will it diminish after the pandemic?" A positive answer indicates that its author inclines to believe in an ephemeral character of online education. The responses demonstrate a high level of uncertainty among the educators. The prevailing majority concentrates in the "Likely yes - Likely not" fields - see Table 14 with a slight dominance of diminishing.

Table 14. Online education is a temporary replacement.

\begin{tabular}{lc}
\hline Agreement level & $\mathrm{N}(\%)$ \\
\hline Certainly yes & $13(7.6 \%)$ \\
Likely yes & $78(45.3 \%)$ \\
Likely not & $64(37.2 \%)$ \\
Certainly not & $17(9.9 \%)$ \\
\hline
\end{tabular}

Some of the open responses were quite pessimistic towards the expansion of online education: "I'm afraid our management will not approve of it." Others suggested a modest approach: "In a stepwise manner, likely yes. An abrupt jump would not be accepted." Finally, there are supporters: "Certainly yes. In my case, it is true even today. There is an online version to my every course." 
Their uncertainty is confirmed by their responses to the next question (see Table 15): "After the pandemic, will the proportion of internet-supported education to total university education grow?"

Table 15. Proportion of online education will grow.

\begin{tabular}{lc}
\hline Agreement level & $\mathrm{N}(\%)$ \\
\hline Certainly yes & $47(27.3 \%)$ \\
Likely yes & $90(52.3 \%)$ \\
Likely not & $30(17.4 \%)$ \\
Certainly not & $5(2.9 \%)$ \\
\hline
\end{tabular}

The data show a more encouraging attitude towards online education. Four out of five educators agree. One possible explanation of the contradiction with the previous data refers to the "not in my backyard" thinking: The proportion will grow but hopefully not in my courses. Finding the right explanation will need additional research.

The expansion of online education will therefore require extensive efforts of university administrators: What individuals to consider as its supporters? To find an answer, we studied Table 16 data from the demographic point of view. Table 16 shows the distribution of the responses among the age groups. Teachers in the groups 20-39 and 60+ displayed almost the same dislike. The age group 40-60 shows a bit lower aversion. The percentages are calculated separately for each age group.

Table 16. Opinions on sustainability of online education among age groups.

\begin{tabular}{lccc}
\hline \multirow{2}{*}{ Online education will diminish } & $20-39$ & $40-60$ & $60+$ \\
& $\mathrm{N}=44(\%)$ & $\mathrm{N}=88(\%)$ & $\mathrm{N}=40(\%)$ \\
\hline Certainly yes & $1(2.8 \%)$ & $6(6.8 \%)$ & $6(15.0 \%)$ \\
Likely yes & $21(47.7 \%)$ & $42(47.7 \%)$ & $15(37.5 \%)$ \\
Likely not & $21(47.7 \%)$ & $29(33.0 \%)$ & $14(35.0 \%)$ \\
Certainly Not & $1(2.8 \%)$ & $11(12.5 \%)$ & $5(12.5 \%)$ \\
\hline
\end{tabular}

The data display both negative and positive findings: the negative one states that if the university administration will decide to expand the portion of online education, there is no age group which could be seen as a carrier of changes. The positive one declares the existence of supportive individuals in every age group.

A gender-based analysis demonstrates more positive insights. As already shown in Table 8 (Learning by teaching), females communicate better with their students compared to their male colleagues. Males' negative experience is likely behind their more pessimistic view of online education perspectives. As displayed in Table 17, 60.9\% of them speak about its certain or probable decline in comparison to the females (48.2\%).

Table 17. Opinions on sustainability of online education by gender groups.

\begin{tabular}{lcc}
\hline Online education will diminish & Males & Females \\
& $\mathrm{N}(\%)$ & $\mathrm{N}(\%)$ \\
\hline Certainly yes & $7(10.9 \%)$ & $6(5.6 \%)$ \\
Likely yes & $32(50.0 \%)$ & $46(42.6 \%)$ \\
Likely not & $17(26.6 \%)$ & $47(43.5 \%)$ \\
Certainly not & $8(12.5 \%)$ & $9(8.3 \%)$ \\
\hline
\end{tabular}




\section{Discussion}

As we have demonstrated, online education affects behaviour of a large social group. The surge in interest in online education (Rojas-Carcia and Ruiz-Luna, 2020) confirms that data obtained in this study coincide with other outcomes e.g., by showing that duration of school closures affects quality of education processes (Unesco, 2021).

Our survey analyses behaviour of educators of Czech and Slovak universities from the outbreak of the COVID-19 pandemic, leading to forced 100\% online education in March 2020, till the peak of its second wave in April-May 2021. The latter date coincides with the period of our survey. The outcomes of the research revealed that Czech and Slovak universities were not prepared for this sudden change. A recent study from Romania (Coman et al., 2020) shows similar results. This corresponds to the statement of Chakraborty et al. (2020) that universities were not prepared for such a transition.

Thus, proper preparation for online study is significant for its success. What is the right approach: synchronous versus asynchronous? Findings regarding online teaching modes before COVID-19 and during the pandemic tend to be both consistent and paradoxical. Data from our survey indicate that, prior to the pandemic, only 11 out of 83 then teaching educators preferred using collaborative (synchronous) communication. The majority used asynchronous communication. Their combination was adopted by 14 educators. Only three educators preferred other formats, especially email or phone calls.

Since the lockdown, a switch of proportions between the main modes has happened. The educators started exploiting the synchronous mode (161) and the combined mode (94) more frequently than the purely asynchronous one (85). The authors agree with Perveen (2016) in that the most suitable online teaching environment consists of both: synchronous and asynchronous paradigms. However, the outcomes of this study are in the vein of another recent study where the synchronous mode proved to be more effective in distance learning (Rigo and Mikuš, 2021).

The insufficient preparation of universities for the change is evident from a low percentage of respondents in our survey reporting receiving training in the content areas. This contradicts Going Virtual survey data, where the majority of respondents did receive training in the field of online teaching and learning (Dawley et al., 2010). On the other hand, our data show that university educators have demonstrated high adaptability in relation to online teaching. After a year of teaching, they evaluate their performance as satisfactory. Nevertheless, their self-evaluation is quite subjective because their experience is casual and training for it non-systematic. They may need primary and additional training in different areas in order to teach more effectively in future. Also, they lack relevant information from their superiors, as one of them says: "I personally perform both on-site and online education at the same quality level. But I have no idea about the future preferences of our management."

According to Seaman (2009), there is a higher rate of female participation in online teaching. The authors agree with Seaman as our sample reflects that male educators (60.9\%) express more negative views on online education perspective compared to their female colleagues (48.2\%). A possible explanation could be different communication styles (Montgomery and Norton, 1981). They describe males as precise and females as animated.

At the same time, the opportunity to watch educators' different points of view could help improve learning effectiveness. The results of our survey are in agreement with those of Muñoz Carril et al. (2013), who discovered that faculties experienced in teaching online are related to increased perception levels of pedagogical competency performance.

The results of our study indicate that more than half the respondents perceive their online education as a temporary replacement. Equivalent to results of one survey, faculty at other universities used to be more pessimistic than optimistic about online learning in the past (Allen et al., 2012). However, students tend 
to be more positive than staff about the role of the virtual learning environment in enhancing their overall performance and experience and as such provide an impetus for further developments with the expectation of improved student retention, performance and satisfaction (Heaton-Shrestha et al., 2009). Provocatively, a recent survey among students suggests that the majority of them (73\%) want more online learning modes in the post-pandemic period (Cengage, 2021). Another recent study recommends adoptions of a fully online remote learning model and a hybrid model in response to students' and parents' requirements (Schwartz et al., 2020). Blended (hybrid) learning contributes constructive learning experiences and includes components that may not be found in traditional, or face-to-face, instruction, and that can foster higher levels of learning (Oliver and Trigwell, 2005). Some data show that many among those who taught online prior to the pandemic are still pessimistic about its future importance. This discrepancy may be due to differences in the population of surveyed educators, their characteristics or their preferences. However, this failure can be connected to teachers' refusal (Heirdsfield et al., 2011) and insufficient professional training (Garrison and Vaughan, 2008). In contrast, findings of another survey declare use of digital tools in both teaching environments (RFA, 2020).

According to the data obtained, online teaching is not able to suppress on-site teaching in the Czech and Slovak Republics soon. However, there will be an increase in the importance of online learning in different forms in the future, similar to data of Schwartz et al. (2020) - and the majority of our surveyed teachers agree. There is also evidence that online learning is financially sustainable when it is a core part of the business practices of an organization (Geith and Vignare, 2008). A suggestion of such incorporation is made by Hvorecký et al. (2021).

There are also negative factors which cannot be neglected. First, at Slovak and Czech universities there are many study programmes having small numbers of students. As a respondents underlines: "In my opinion, there are risks, too - further fragmentation of study programmes and groups as well as disintegration of systematic appropriation of study content." There are also health risks (Heiden et al., 2020). Some of our respondents also pointed to them: "Soon, I started feeling pain in my back and right hand plus eye fatigue."

Also, "learning by doing" should not be the only way of getting educated in online communication. This type of education can lead to persisting wrong habits on both sides - among educators and learners. Universities should start working on their elimination. As many respondents stressed, their communication with the students failed or almost failed as a result of their "cutting off" their communication for various reasons including insufficient capacity of servers for fully synchronous courses. Some universities did not require their students to activate their cameras with a reference to GDPR (Regulation of EC, 2016). That led to stress and risks of low-quality teaching practices e.g., in individual and team projects, or plagiarism. Without fixing these sources of potential problems, an extensive transition to the virtual space would be a premature act.

\section{Conclusions}

Our survey analyses behaviour of educators of Czech and Slovak universities from the outbreak of the COVID-19 pandemic, leading to forced 100\% online education in March 2021, to the peak its second wave in May 2020. In response to it, we developed an educator survey and deployed it across Czech and Slovak universities. Its main aim was to explore educators' flow of online education and its changes during the pandemic.

The survey findings, which represent the experience and needs of 172 educators (67 from Czech universities and 105 from Slovakian ones), demonstrate that Czech and Slovak universities were not prepared for this sudden change and still struggle with problems. In pre-COVID times, there was a low rate of trained educators. Luckily for the sake of universities, our data indicate educators' high capability 
of adaptation to their new online learning environment. Their adaptation time was short, mostly within three weeks after the lockdown. We compared four specified methods used by the teachers and showed that their application was extended significantly. In particular, the data suggest that the synchronous teaching mode is an effective short-term solution.

Indeed, after more than a year of teaching in the online environment, educators evaluate their performance as satisfactory overall. Nevertheless, additional data from our survey demonstrate that more than half the respondents consider their online education a temporary replacement. This may mean that instead of interpreting this unexpected event as a unique opportunity for the universities, their management and staff to analyse some unknown features of university education (in which they succeeded), many lecturers remain sceptical. Based on our outcomes, we suggest that they analyse their strengths and gaps and reflect them in their university strategy, pinpoint opportunities for improvements and amplify the needs which become visible during enforced full online learning.

This study could facilitate the identification of how online learning has changed both teachers and the teaching profession in higher education, why many universities remain ambivalent about online teaching, and suggests ways to address these challenges in the surveyed countries. Its respondents were limited to a group of Czech and Slovak volunteers so the picture can be distorted. Its expansion to a representative sample covering the European Union would certainly say more about the position of universities towards the future of online education.

Further limitation can be detected in unintentional deviations in translations of the survey into the target languages.

Future research will therefore focus on how to design and improve the quality and dynamic of online content as well as on the role of university management in these processes. Additionally, future investigation could concentrate on hybrid online learning rather than either fully online or fully traditional on-site learning. Alternatively, such investigation may explore the relationships between online educators and students with their identities and patterns of adoption or rejection. Another direction of future work will examine connections between online learning and remote work.

\section{Additional Information and Declarations}

Acknowledgements: The authors express their gratitude to all educators who voluntarily participated in the survey.

Funding: This research was partially supported by the projects: No. 7429/2020/02 "System approach to selected ICT trends" of the University of Finance and Administration in Prague, Czech Republic; VEGA no. 1/0420/19: "Importance of trade cooperation of the EU and the countries of the Western Balkans - company expansion perspective" by the Ministry of Education, Science, Research and Sports of the Slovak Republic; VEGA no. 1/0777/20: "Belt and Road initiative - opportunity or threat for the EU and Slovak export competitiveness" by the Ministry of Education, Science, Research and Sports of the Slovak Republic.

Conflict of Interests: The authors declare no conflict of interest.

Author Contributions: J.H.: Conceptualization, Data curation, Formal analysis, Methodology, Project administration, Supervision, Writing - original draft, Writing - review \& editing. M.B.: Conceptualization, Formal analysis, Methodology, Writing - original draft, Writing - review \& editing. S.F.: Data curation, Supervision, Writing - review \& editing. R.J.: Data curation, Supervision, Writing - review \& editing. J.Š.: Data curation, Supervision, Writing - review \& editing. 
Data Availability: The data that support the findings of this study are available from the corresponding author.

\section{References}

Abou El-Seoud, S., Seddiek, N., Taj-Eddin, I., Ghenghesh, P., Nosseir, A., \& El-Khouly, M. (2014). E-Learning and Students' Motivation: A Research Study on the Effect of E-Learning on Higher Education. International Journal of Emerging Technologies in Learning, 9(4), 20. https://doi.org/10.3991/ijet.v9i4.3465

Ahmadi, J., \& Nourabadi, S. (2020). Implementation barriers in virtual education in Payame Noor University in Iran. Utopía y Praxis Latinoamericana, 25(2), 202-209.

Allen, I. E. \& Seaman, J. (2010). Class differences: Online education in the United States. Babson Survey Research Group.

Allen, I. E., Seaman, J., Lederman, D., \& Jaschik. S. (2012). Conflicted: Faculty and online education. Inside Higher Ed \& Babson Survey Research Group.

Andrade, M. S. (2016). Online Learning: Strategies for Pedagogical Retooling. In Proceedings of the 8th International Conference on Computer Supported Education (CSEDU 2016) - Volume 2, (pp. 85-90). SCITEPRESS.

Aristovnik, A., Keržič, D., Tomaževič, N., \& Umek, L. (2016). Determining Factors of Students' Perceived Usefulness of Elearning in Higher Education. In International Conference e-Learning, (pp. 3-10). International Association for the Development of the Information Society.

Aslanian, C. (2001). You're never too old: Excerpts from adult students today. Community College Journal, 71(5), 56-58.

Barkhartova, D., Nigmatulina, E., \& Stepanova, T. (2017). Social Informatics: Natural Tools for Students' Information Training in The Conditions of Embodied and Mental Approaches Being Employed. Journal of Social Studies Education Research, 8(2), 100-116.

Barker, A. (2003). Faculty development for teaching online: Educational and technological issues. The Journal of Continuing Education in Nursing, 34(6), 273-278.

Beblavý, M., Baiocco, S., Kilhoffer, Z., Akgüc, M., \& Jacquot, M. (2019). Index of Readiness for Digital Lifelong Learning. https://www.ceps.eu/download/publication/?id=25419\&pdf=Index-of-Readiness-for-Digital-Lifelong-Learning.pdf

Burçin Hamutoğlu, N., N Ünveren-Bilgiç, E., Cem Salar, H., \& L Şahin, Y. (2021). The Effect of E-Learning Experience on Readiness, Attitude, and Self-Control/Self-Management. Journal of Information Technology Education: Innovations in Practice, 20, 093-120. https://doi.org/10.28945/4822

Carey, K. (2020, March 13). Everybody Ready for the Big Migration to Online College? Actually, No. https://www.nytimes.com/2020/03/13/upshot/coronavirus-online-college-classes-unprepared.html

Cengage. (2021). Digital Learning Pulse Survey Findings. https://info.cengage.com/LP=5443

Chakraborty, P., Mittal, P., Gupta, M. S., Yadav, S., \& Arora, A. (2020). Opinion of Students on Online Education during The COVID -19 Pandemic. Human Behavior and Emerging Technologies, 3(3), 357-365. https://doi.org/10.1002/hbe2.240

Chizmar, J. F., \& Williams, D. B. (2001). What do faculty want?. https://www.educause.edu/ir/library/pdf/eqm0112.pdf

Coman, C., Țîru, L. G., Meseșan-Schmitz, L., Stanciu, C., \& Bularca, M. C. (2020). Online Teaching and Learning in Higher Education during the Coronavirus Pandemic: Students' Perspective. Sustainability, 12(24), 10367. https://doi.org/10.3390/su122410367

Conrad, D. (2004). University instructors' reflections on their first online teaching experiences. Journal of Asynchronous Learning Networks, 8(2), 3-44.

Cox, M. J., \& Marshall, G. (2007). Effects of ICT: Do we know what we should know? Education and Information Technologies, 12(2), 59-70. https://doi.org/10.1007/s10639-007-9032-x

Currie, G., Hewis, J., Nelson, T., Chandler, A., Nabasenja, C., Spuur, K., Barry, K., Frame, N., \& Kilgour, A. (2020). COVID-19 impact on undergraduate teaching: Medical radiation science teaching team experience. Journal of Medical Imaging and Radiation Sciences, 51(4), 518-527. https://doi.org/10.1016/j.jmir.2020.09.002

Davidekova, M., \& Hvorecky, J. (2017). ICT Collaboration Tools for Virtual Teams in Terms of the SECI Model. International Journal of Engineering Pedagogy, 7(1), 95. https://doi.org/10.3991/ijep.v7i1.6502

Dawley, L., Rice, K., \& Hinck, G. (2010). Going Virtual! The Status of Professional Development and Unique Needs of K-12 Online Teachers. https://aurora-institute.org/wp-content/uploads/goingvirtual3.pdf

Dhawan, S. (2020). Online Learning: A Panacea in the Time of COVID-19 Crisis. Journal of Educational Technology Systems, 49(1), 5-22. https://doi.org/10.1177/0047239520934018

Ditacademy. (2017). Is Online Learning Effective Learning?. https://ditacademy.org/wp-content/uploads/2017/08/OnlineLearning-Effective.pdf

Duffin, E. (2020). E-learning and digital education. https://www.statista.com/topics/3115/e-learning-and-digital-education/

Espinoza, C. (2012). Millennial values and boundaries in the classroom. New Directions for Teaching and Learning, 2012(131), 29-41. https://doi.org/10.1002/tl.20025

Eurostat. (2021). Individuals - internet use. https://ec.europa.eu/eurostat/databrowser/view/isoc ci ifp iu/default/bar?lang=en 
Franklin, U., \& Nahari, A. (2018). The Impact of E-Learning on Academic Performance: Preliminary Examination of King Khalid University. International Journal of Academic Research in Progressive Education and Development, 7(1), 83-96. https://doi.org/10.6007/IJARPED/v7-i1/3903

Fricker, R. D. (2015). Sampling Methods for Online Surveys. In The SAGE Handbook of Online Research Methods (Chapter 10). SAGE. https://doi.org/10.4135/9781473957992.n10

Garrison, D. R., \& Vaughan, N. D. (2012). Blended Learning in Higher Education: Framework, Principles, and Guidelines. Jossey-Bass.

Gedeon, P., \& Khalil, L. (2015). Management of the Transition to e-Learning in Higher Education Based on Competence Quotient. Procedia Computer Science, 65, 324-332. https://doi.org/10.1016/j.procs.2015.09.091

Geith, C., \& Vignare, K. (2008). Access to Education with Online Learning and Open Educational Recourses: Can They Close the Gap?. Journal of Asynchronous Learning Networks, 12(1), 105-126.

Gerasimova, V. G., Melamud, M. R., Tutaeva, D. R., Romanova, Y. D., \& Zhenova N. A. (2018). The Adoption of E-Learning Technology at the Faculty of Distance Learning of Plekhanov Russian University of Economics. Journal of Social Studies Education Research, 9(2), 172-188.

Gokah, T. K., Gupta, N., \& Ndiweni, E. (2015). E-Learning in Higher Education - Opportunities \& Challenges for Dubai. International Journal on E-learning, 14(4), 443-470.

Hall, R., Drál', P., Fridrichová, P., Hapalová, M., Lukáč, S., Miškolci, J., \& Vančíková, K. (2019). Analýza zistení o stave školstva na Slovensku: To dá rozum. https://analyza.todarozum.sk/analyza-zisteni-o-stave-skolstva-na-slovensku.pdf

Kazmer, M. M., \& Haythornthwaite, C. (2005). Multiple perspectives on online learning. ACM SIGGROUP Bulletin, 25(1), 711. https://doi.org/10.1145/1067699.1067701

Heaton-Shrestha, C., May, S., \& Burke, L. (2009). Student retention in higher education: what role for virtual learning environments? Journal of Further and Higher Education, 33(1), 83-92. https://doi.org/10.1080/03098770802645189

Heiden, M., Widar, L., Wiitavaara, B., \& Boman, E. (2021). Telework in academia: associations with health and well-being among staff. Higher Education, 81, 707-722. https://doi.org/10.1007/s10734-020-00569-4

Heirdsfield, A., Walker, S., Tambyah, M., \& Beutel, D. (2011). Blackboard As An Online Learning Environment: What Do Teacher Education Students And Staff Think? Australian Journal of Teacher Education, 36(7), 1-16. https://doi.org/10.14221/ajte.2011v36n7.4

Higher Education Academy. (2015). Framework for flexible learning in higher education. The Higher Education Academy. https://www.heacademy.ac.uk/enhancement/frameworks/framework-flexible-learning-higher-education

Hvorecký, J., \& Beňo, M. (2021). Linkages between PISA Results and E-Working. Emerging Science Journal, 5(3), $294-304$. https://doi.org/10.28991/esj-2021-01277

Hvorecký, J., Beňo, M., \& Janošcová, R. (2021). Online Education as an Integral Part of Universities' Strategy. In Proceedings of the 15th International Technology, Education and Development Conference, (pp. 5197-5205). IATED. https://doi.org/10.21125/inted.2021.1066

Isaac, S., \& Michael, W. B. (1997). Handbook in Research and Evaluation: A Collection of Principles, Methods, and Strategies Useful in the Planning, Design, and Evaluation of Studies in Education and the Behavioral sciences. Educational and Industrial Testing Services.

Janošcová, R., \& Hvorecký, J. (2020). Massification of Online Education: A Holistic Strategy. In 2020, 18th International Conference on Emerging eLearning Technologies and Applications (ICETA), (pp. 226-235). IEEE. https://doi.org/10.1109/ICETA51985.2020.9379275

Keegan, L. (2021). 79+ Staggering Online Learning Statistics! (All You Need To Know). https://skillscouter.com/online-learningstatistics

Kim, H. J., Hong, A. J., \& Song, H.-D. (2019). The roles of academic engagement and digital readiness in students' achievements in university e-learning environments. International Journal of Educational Technology in Higher Education, 16(1). https://doi.org/10.1186/s41239-019-0152-3

King, A. (1993). From Sage on the Stage to Guide on the Side. College Teaching, 41(1), 30-35. https://doi.org/10.1080/87567555.1993.9926781

Kling, R. (2007). What Is Social Informatics and Why Does It Matter? The Information Society, 23(4), $205-220$. https://doi.org/10.1080/01972240701441556

Kling, R., Rosenbaum, H., \& Sawyer, S. (2005). Understanding and communicating social informatics: A framework for studying and teaching the human contexts of information and communication technologies. Information Today.

Lichoro, D. M. (2015). Faculty preparedness for transition to teaching online courses in the lowa Community College Online Consortium. https://lib.dr.iastate.edu/cgi/viewcontent.cgi?article $=5383 \&$ context=etd

Liguori, E., \& Winkler, C. (2020). From Offline to Online: Challenges and Opportunities for Entrepreneurship Education Following the COVID-19 Pandemic. Entrepreneurship Education and Pedagogy, 3(4), 251512742091673. https://doi.org/10.1177/2515127420916738

Lipovská, L., Hvorecký, J., \& Šimúth, J. (2014). Virtuálna trieda. Equilibria.

Makoe, M., Richardson, J. T. E., \& Price, L. (2007). Conceptions of learning in adult students embarking on distance education. Higher Education, 55(3), 303-320. https://doi.org/10.1007/s10734-007-9056-6 
Mitchell, A. (2014). Online Courses and Online Teaching Strategies in Higher Education. Creative Education, 5(23), 20172019. https://doi.org/10.4236/ce.2014.523225

Montgomery, B. M., \& Norton, R. W. (1981). Sex differences and similarities in communicator style. Communications Monographs, 48(2), 121-132.

Moodle. (2021). Moodle registration map, Europe. https://stats.moodle.org/

Muñoz Carril, P. C., González Sanmamed, M., \& Hernández Sellés, N. (2013). Pedagogical roles and competencies of university teachers practicing in the e-learning environment. The International Review of Research in Open and Distributed Learning, 14(3), 462. https://doi.org/10.19173/irrodl.v14i3.1477

Naderifar, M., Goli, H., \& Ghaljaie, F. (2017). Snowball sampling: A purposeful method of sampling in qualitative research. Strides in Development of Medical Education, 14(3). https://doi.org/10.5812/sdme.67670

NCES. (2019). Distance Learning. https://nces.ed.gov/fastfacts/display.asp?id=80

OECD. (2020). Youth and COVID-19: Response, Recovery and Resilience. https://read.oecdilibrary.org/view/?ref=134 134356-ud5kox3g26\&title=Youth-and-COVID-19-Response-Recovery-andResilience\& ga $=2.223238427 .1658317499 .1627300176-1787920977.1626341665$

Oliver, M., \& Trigwell, K. (2005). Can "Blended Learning" Be Redeemed?. E-Learning and Digital Media, 2(1), 17-26. https://doi.org/10.2304/elea.2005.2.1.17

Palloff, R. M., \& Pratt, K. (2007). Building Online Learning Communities: Effective Strategies for the Virtual Classroom. Jossey-Bass.

Perveen, A. (2016). Synchronous and Asynchronous E-Language Learning: A Case Study of Virtual University of Pakistan. Open Praxis, 8(1), 21-39.

Ponto, J. (2015). Understanding and Evaluating Survey Research. Journal of the Advanced Practitioner in Oncology, 6(2), $168-171$.

Preply. (2020). Methodik “Um Klassen smarter: Digitale Bildung iminternationalen Vergleich”. https://preply.com/de/d/elearning-index/files/full\%20report-e-learning-index-preply.pdf

RFA. (2020). Teacher Use of Digital Tools: Results of a Survey of District Teachers in Philadelphia, Pittsburgh, Scranton and Neshaminy. https://8rri53pm0cs22jk3vvqna1ub-wpengine.netdna-ssl.com/wp-content/uploads/2020/09/RFA-SurveyResults-Teaching-Tools-during-Covid-19.pdf

Regulation of EC. (2016). Regulation (EU) 2016/679 of the European Parliament and of the Council of 27 April 2016 on the protection of natural persons with regard to the processing of personal data and on the free movement of such data, and repealing Directive 95/46/EC (General Data Protection Regulation). http://data.europa.eu/eli/reg/2016/679/oj

Rigo, F., \& Mikuš, J. (2021). Asynchronous And Synchronous Distance Learning of English As a Foreign Language. Media Literacy and Academic Research, 4(1), 89-106.

Rojas-Garcia, C. R., \& Ruiz-Luna, A. (2020). The Surge of e-learning during the 2020 Covid-19 Crisis: Threat or Promise? An Exploration and Conversation with a Professional in Education. In The Impact of COVID19 on the International Education System, (pp. 55-70). Proudpen. https://doi.org/10.51432/978-1-8381524-0-6 4

Salmon, G. (2011). E-Moderating: The Key to teaching and Learning Online. Routledge.

Schwartz, H. L., Grant, D., Diliberti, M. R., Hunter, G. P., \& Setodji, C. M. (2020). Remote Learning Is Here to Stay. Results from the First American School District Panel Survey. https://www.rand.org/pubs/research reports/RRA956-1.html

Seaman, J. (2009). Online Learning as a Strategic Asset. Volume II: The Paradox of Faculty Voices: Views and Experiences with Online Learning. https://files.eric.ed.gov/fulltext/ED517311.pdf

Sener, J. E. (2010). Why Online Education Will Attain Full Scale. Online Learning, 14(4), 3-16. https://doi.org/10.24059/olj.v14i4.152

ThinkImpact. (2021). eLearning Statistics. https:/www.thinkimpact.com/elearning-statistics/

Turner, A. (2015). Generation Z: Technology and Social Interest. The Journal of Individual Psychology, 71(2), $103-113$. https://doi.org/10.1353/jip.2015.0021

Unesco. (2021). Total duration of school closures. https://en.unesco.org/covid19/educationresponse

Valverde-Berrocoso, J., Garrido-Arroyo, M. del C., Burgos-Videla, C., \& Morales-Cevallos, M. B. (2020). Trends in Educational Research about e-Learning: A Systematic Literature Review (2009-2018). Sustainability, $12(12), 5153$. https://doi.org/10.3390/su12125153

Vadakalu Elumalai, K., P Sankar, J., R, K., Ann John, J., Menon, N., Salem M Alqahtani, M., \& Abdulaziz Abumelha, M. (2020). Factors Affecting the Quality of E-Learning During the COVID-19 Pandemic from the Perspective of Higher Education Students. Journal of Information Technology Education: Research, 19, 731-753. https://doi.org/10.28945/4628

Vehovar, V. (2006). Social Informatics: An Emerging Discipline?. In Berleur J., Nurminen M.I., Impagliazzo J. (eds.) Social Informatics: An Information Society for all? (pp. 73-85). Springer. https://doi.org/10.1007/978-0-387-37876-3 6

Wegner, S. B., Holloway, K. C., \& Garton, E. M. (2019). The Effects of Internet-Based Instruction on Student Learning. Online Learning, 3(2). https://doi.org/10.24059/olj.v3i2.1920

Zolochevskaya, E. Yu., Zubanova, S. G., Fedorova, N. V., \& Sivakova, Y. E. (2021). Education policy: the impact of elearning on academic performance. In E3S Web of Conferences, vol. 244, 11024. EDP Sciences. https://doi.org/10.1051/e3sconf/202124411024 
Zuvic-Butorac, M., Roncevic, N., Nemcanin, D., \& Nebic, Z. (2011). Blended E-Learning in Higher Education: Research on Students' Perspective. Issues in Informing Science and Information Technology, 8, 409-429. https://doi.org/10.28945/1427

Editorial record: The article has been peer-reviewed. First submission received on 1 August 2021. Revision received on 14 September 2021, 28 September 2021 and 15 October 2021. Accepted for publication on 23 October 2021. The editors coordinating the peer-review of this manuscript were Vasja Vehovar (D), Zdenek Smutny (D), and Alice R. Robbin (D). The editor in charge of approving this manuscript for publication was Zdenek Smutny.

Special Issue: Perspectives of Social Informatics.

Acta Informatica Pragensia is published by Prague University of Economics and Business, Czech Republic.

ISSN: 1805-4951 